$\$$ Research Square

\title{
Impact of Remittances Inflows and Macroeconomic Stability on Poverty in Nigeria (1977-2014)
}

Anthony 0. Onoja ( $\nabla$ tonyojonimi@gmail.com )

https://orcid.org/0000-0003-2864-1574

\section{Clarietta Chagwiza}

University of Pretoria Faculty of Natural and Agricultural Sciences https://orcid.org/0000-0002-00200753

\section{Research}

Keywords: foreign migration, poverty alleviation, Autoregressive distributed lag model, household per capita consumption, welfare

Posted Date: July 27th, 2020

DOl: https://doi.org/10.21203/rs.3.rs-46739/v1

License: (9) This work is licensed under a Creative Commons Attribution 4.0 International License.

Read Full License 


\section{Impact of Remittances Inflows and Macroeconomic Stability on Poverty in}

\section{Nigeria (1977-2014)}

Anthony O. Onoja ${ }^{1 *}$, Clarietta Chagwiza ${ }^{2}$

${ }^{1}$ Department of Agricultural Economics and Extension, University of Port Harcourt, PMB 5323, Choba, Port Harcourt, Nigeria

${ }^{2}$ Dept. of Agricultural Economics, Extension and Rural Development, University of Pretoria, South Africa *E-mail: anthony.onoja@uniport.edu.ng [alternative e-mail: tonyojonimi@gmail.com]

\section{Abstract}

The study explored the trend and effects of macroeconomic conditions on poverty (using household consumption as proxy for poverty) in Nigeria. It also analyzed how foreign migration remittances affect aggregate household poverty. It relied on secondary data analyzed using trend and cointegration analysis. It was found that on the long run, when gleaned from the perspective of aggregate household consumption, level of poverty in the country could be explained by economic growth (GDP per capita current USD, lngdp), volume of export trade as percentage of GDP (lnexptrgdp), official exchange rate of Nigerian Naira to USD (lnforex), inflation rate (lninf) and age dependency ratio of population (proxy for aggregate level of unemployment) (lnagedprat). Efforts must be put in place to promote youth employment opportunities, export market access to Small and medium scale enterprises, proper management of foreign exchange regimes. Since migration is not a sustainable source of income for the country, Nigerian authorities must provide education and skills acquisition opportunities too and enhanced working conditions to reduce dependency on immigration as a source of poverty reduction in households.

Keywords: foreign migration, poverty alleviation, Autoregressive distributed lag model, household per capita consumption, welfare 


\section{Introduction}

The United Nations (2016) indicated that the number of international migrants — persons living in a country other than where they were born — reached 244 million in 2015 for the world as a whole, a 41 percent increase compared to 2000. The number of international migrants is growing faster than the world's population (Iyare 2016). The Global Migration Data Analysis Centre (GMDAC) in 2016 (cited by Iyare 2016) observed that an estimated total of 341,055 arrived some key parts of Europe through the Mediterranean Sea route, while 4,271deaths were recorded. When compared to 2015, from 1st January - 13th November 2016, there were 728, 926 arrivals and 3,522 deaths recorded. Despite such alarming figures, 3 million migrants are still expected in the European Union (EU) in 2017, compared to 1.5 million in 2016 (Iyare 2016). This surge in international migration has become a critical issue in not just countries where these migrants emerge, but a global threat that requires urgent global attention. Hundreds of thousands of migrants have reportedly fled their countries seeking asylum as refugees in European countries over the years, the report noted. About $90 \%$ of the migrants originated from countries such as Syria, Afghanistan, Nigeria, Mexico, Iran where there are high security risks, insurgency, humanitarian crisis, war, poverty, human rights abuses, among others. The UN Under-SecretaryGeneral for Economic and Social Affairs (Mr. Wu Hongbo) noted that "the rise in the number of international migrants reflects the increasing importance of international migration, which has become an integral part of our economies and societies" (United Nations 2016). He concluded that well-managed migration brings important benefits to countries of origin and destination, as well as to migrants and their families.

The good news is that for the first time ever, migration is included in the global development framework, recognizing well-managed migration's integral role as having immense contribution to sustainable development (International Organization for Migration (IOM) 2016). The Sustainable Development Goals of the United Nations (SDGs) are now driving policy planning 

8

and implementation across borders and across sectors, recognizing the interlinkages between migration and development and the fundamental contributions of migrants. Of particular relevance worth of reference to this study is the SDG target 10 . C, which intends to, "by 2030, reduce to less than $3 \%$ the transaction costs of migrant remittances and eliminate corridors with costs higher than 5\%." As the international community moves forward, mobilizing, implementing and monitoring the new Agenda, there is a need to provide evidence to support policy making that will help attain the SDG through a study of this kind, hence the need for this study.

Nigeria has been a major international migration destination in the past, although this flow was affected by civil strife in the 1970s, and was dramatically reversed with the expulsion of about a million Ghanaian and other foreign workers in 1983 (Arthur 1991 as cited in Black et al. 2004). Since that time and during the era of deregulation, migration in Nigeria has been characterised by emigration, as well as substantial amounts of internal migration (Black et al. 2004). Black et al (2004) reported that whilst migration had a number of positive benefits, problematic aspects of migration were noted in the literature that could specifically impact the poorest. The Food and Agricultural Organization (FAO) (as cited in Black et al, 2004) argued that mobility of members of farming households was partly responsible for seasonal labour shortages and an ageing of onfarm populations, with a negative effect on agricultural productivity. In addition, trafficking in West Africa is seen by many agencies as 'pervasive and growing', falling into two main types: (i) the trafficking of children mainly for domestic and agricultural work both across and within national borders; and (ii) the trafficking in women and children for sexual exploitation, mainly to outside the region. These type of migration from Nigeria usually head to Europe, the Middle East and other parts of Africa. However, although figures are available on the extent of these two phenomena, they are often unreliable observed by Black et al. (2004). 
1 According to Osili (2001), the international migration of highly skilled labour and other Nigerians

2 to developed countries was not entirely negative. The report noted that the Federal Reserve Bank of Chicago estimated that Nigerians in the US alone sent $\$ 1.3$ billion each year, or more than six times the annual flow of US aid back to Nigeria. A small sample survey of just over 100 Nigerians in Chicago, the report noted, found an average remittance of $\$ 6,000$ per year, with 60 per cent of this going to basic household needs, and remittances higher where households in Nigeria are poorer, other factors being held constant. Financial flows can also go in the opposite direction: e.g. there appear to be substantial outflows of Nigerian oil wealth to Nigerians abroad (Blench, 2004).

Iyare (2016) noted that most Nigerians who braved the stormy seas and unfriendly deserts have

lost hope in an economic system that was characterized by poor governance, poor income, unemployment, insecurity, corruption, humanitarian crisis, increasing poverty, which has led to a high surge of migration. The United Nations Department of Economics and Social Affairs, observed that since 2010 to 2016, emigrants and migrants, in and out of Nigeria, when compared amounted to a minimum difference of 60,000 who left the shores of the country yearly. Many of these migrants were sold into prostitution, child labour, and slavery to countries like Libya, Spain, and Italy. In 2016 alone, not less than 162 Nigerians were repatriated in Libya, 41 from USA, and 40 from the UK etc. Data from the EU indicated that an average of 83 Nigerians crossed illegally from Nigeria to Europe, daily, while 22,500 illegally crossed via the Mediterranean in the first nine months of 2016. Iyare (2016) suggested that in Nigeria, there was correlation between poverty, corruption, war and migration on the other hand. Even though, it was not an empirical study, Iyare maintained that the startling record of human rights abuses, poverty, unemployment and insecurity were major reasons for the increase in migration since the past two decades. Nigeria still remains one of the poorest countries in the world. The poverty head count ratio in the country decreased from $48.4 \%$ in 2003 to $46 \%$ in 2009 while the GINI index (index of inequality) grew from 40.06 in 2003 to 42.97 in 2009 (World Bank 2016). 
2 According to Imai et al. (2014), most studies exploring the relationship between migration and

economic growth or poverty have erstwhile depended on cross sectional data. This study differs by using a time series modelling to explore the possible link between migration remittances and aggregate consumption (our proxy for welfare growth). It is not clear in empirical terms how foreign migration remittances alongside macroeconomic factors have contributed to poverty levels of emigrants' countries (especially that of Nigeria). Therefore, an empirical investigation into such relationships as this current will give policy makers evidence on relationship between foreign immigration incentives and poverty alleviation drive in emigrating countries. Results can inform policymakers better on the right tools to use in formulating and implementing policies that will effectively tackle global poverty and how to effectively manage immigration crises thus contributing to attaining the Sustainable Development Goals.

The aim of this research therefore, is to find the nexus between welfare and international migration. Specifically the study seeks to: (i) chart and analyze the trend of foreign immigration remittances by Nigerian international emigrants from 1977 to 2014 alongside the trend of migration in Nigeria over the same period; and (ii) determine the effects of foreign migration remittances by Nigerian international emigrants alongside the macro-economic conditions on the welfare (aggregate household consumption) of Nigerians.

\section{Relationship between migration remittances and migrants' home economy}

There are mixed results about the effects of migration on the economy of the migrants' home countries. A research conducted by Imai et al. (2014) in Asia established a link between migration remittances and poverty reduction. From the Micro-economic theoretical point of view, potential migrants are believed to be attracted by income differentials between regions, or by differences in the present value of life-time income streams (Sjaastad 1962, Chiswick 2000 as cited in 
1 Gelderblom 2006) or probably by wage differential levels between regions, corrected for the

2 probability of seeing employment in the destination area (Todaro 1976). Thus, if the expected

3 income gains derivable from a move from place A to place B is higher than the costs of migration,

4 a potential migrant is expected to move (Bauer and Zimmermann 1995; Chiswick 2000).

5 Gelderblom (2006) therefore concluded that poverty and unemployment were therefore the major

6 push factors in the area of origin, and the possibility of employment and an improved income major pull factors in the destination area. Some studies have found that migration remittances, after such labour push have exerted positive relationship between remittances and economic growth to the extent that they significantly contributed to the value added in agriculture, manufacturing and service sectors of the economy (Nyan 2013). The insight from the foregoing gave the author evidence to assume that aggregate consumption expenditure in Nigeria could be affected by remittances since remittances are used in consumption by households and partly for investments. According to Glystos (1993) most remittances are spent on consumption but a substantial part goes into housing and a moderate amount into investment. Glystos' report corroborated this using a report in which he indicated that $62.6 \%$ of remittances from migrants in their home countries (Greece and Germany) were spent on consumption.

Some other few researches such as Chowdhury (2011), Aggarwal et al. (2011) Giuliano and RuizArranz (2009) affirmed the positive relationship between remittances and financial development. A sound financial development in an economy, in this case, the migrant home country, can improve the aggregate consumption power of home country. They noted that this relationship tends to improve the economy in the home country. On the other hand, some researchers noted that, increase in remittances inflow, however, might deteriorate the institutional quality of the home country of the migrants (Abdih et al. 2011) on the long run. With respect to other possible determinants of aggregate household consumption, a recent study by Bonsul and Muzindutsi 
1 (2017) indicated that income, inflation and the real exchange rate exerted significant positive long-

2 run effects on household consumption expenditure in Ghana.

3

4

5

\section{Research Methods}

The study area is Nigeria. Located in West Africa, Nigeria is the most populous and largest economy in Africa yet still immersed in poverty and have documented cases of high population of her citizens involved in foreign emigration (Iyare, 2016) as stated in the background of this paper. According to World Bank (2016), Nigeria's population stood at 182.2 million (2015 estimates) with a GDP of $\$ 481.1$ billion; GDP growth of $2.7 \%$ and inflation rate of $9.0 \%$, all at 2015 estimates.

The study adopted a survey approach to econometrically determine the relationship between aggregate poverty and foreign migration remittances to Nigeria over a period of 39 years. It relied primarily on secondary data from World Bank World Development Index (WDI) and Central Bank of Nigeria (CBN) spanning from 1977 to 2014. The sampling method was a purposive sampling method based on period when data on all the variables of interest were available in the time series data from the institutional data used.

The key approach in this paper is similar to Mukherjee and Benson (2003) as cited and adopted in Grounder (2012) which is based on modelling the natural logarithm of total per capita consumption of households, an indicator of household welfare, against a set of exogenous determinants. However, this present study differs in the sense that this study looks at the role of foreign migration remittances as an explanatory variable (or determinant) among other macroeconomic factors in determining aggregate per capita household consumption in Nigeria. 
1 The major data utilized in this study included natural logs of selected time series data briefly listed

2 as follows:

\section{Dependent Variable (lnhshdc): Households' final consumption Expenses}

Studies from Pradhan (2009), World Bank (2003) and Hamburger (1954) affirmed the usefulness of data on household consumption to serve as a proxy for poverty in welfare analysis of households even though they acknowledged other diverse measures of poverty. According to Central Bank of Nigeria (2015), Private Consumption also known as Household actual final consumption consists of the consumption of goods or services acquired by individual households by expenditures or through social transfers in kind, received from government units or Non-Profit Institutions Serving Households (NPISHs). The value of household actual final consumption is given by the sum of the two components: a) The value of household expenditures on consumption goods or services including expenditures on non-market goods or services sold at prices that are not economically significant. and b) The value of the expenditures incurred by the NPISH, on Individual consumption goods or services provided households as social transfers in kind. In a recent empirical analysis of a similar relationship in Botswana, Musakwa and Odhiambo (2019) adopted household consumption expenditure as a proxy to measure aggregate poverty.

\section{Explanatory Variables tested are as follows:}

\section{Economic Growth (GDP) GDP per capita current USD and Aggregate Poverty}

The International Monetary Fund (IMF) (2001) indicates that economic growth remains the single most important factor influencing poverty They acknowledge that various statistical studies have provided strong links between national per capita income and national poverty indicators. The Department for International Development (DFID) (undated) too notes that economic growth remains the most potent tool for poverty reduction and improvement of standard of living in developing countries. It showed that cross-country and country case studies have provided 
overwhelming evidence to justify the fact that rapid and sustained growth is critical to generating virtuous circles of prosperity and opportunity. However, the caveat DFID gave is that "the extent to which growth reduces poverty depends on the degree to which the poor participate in the growth process and share in its proceeds." Hence DFID recommends the promotion of rapid and sustained economic growth which is environmentally sustainable to implement a successful strategy of poverty reduction. Hence in this study the apriori expectation is that GDP growth may influence poverty (aggregate consumption) either positively or negatively.

\section{Export Trade and Aggregate Poverty}

United Nations Conference on Trade and Development, UNCTAD (2013) notes that trade plays a major role in job creation and poverty reduction globally. It recommends policies that will engender countries' competitiveness and increasing exports. This should also include poverty reduction through "breaking into global value chains (GVCs) to generate employment or to replace imports and restore production so that jobs return." They also showed that trade can facilitate decrease of inequality between countries but could also result in increase of inequality within countries. It is against this backdrop that this study tests the hypothesis to affirm the possibility of Export Trade calculated as exports of goods and services as percentage of GDP (\%) (coded as lnexptrgdp) exerting any significant effect on aggregate consumption.

\section{Foreign Exchange Regimes, Inflation and Poverty (aggregate consumption)}

IMF (2001) aptly indicates that when formulating a country's poverty reduction strategy, policymakers must assess and determine what should constitute the most appropriate mix of key macroeconomic targets that can ensure macroeconomic stability in their particular circumstance. Three macroeconomic factors that can affect economic stability and consequently affect poverty include inflation and foreign exchange regimes in the country as well as the levels of foreign direct investments. IMF (2001) further notes that "monetary and exchange rate policies can affect 
1 the poor primarily through three channels: inflation, output, and the real exchange rate." Inflation,

2 they note hurts the poor. This is because inflation acts as a regressive tax and restricts growth.

3 When aggregate output fluctuates it has a very direct impact upon the incomes of the poor. IMF

4 adds that that monetary and exchange rate policies affect such fluctuations in two ways: first,

5 fluctuations in the aggregate money supply can exert short-run effect on real variables such as the

6 real interest rate, which in turn can affect output; secondly, a country's chosen exchange rate

7 regime may buffer or amplify external shocks in the economy.

Remittances inflows and Poverty Reduction

Empirical studies have linked foreign migration with poverty reduction. For instance, in a study conducted to ascertain the impact of foreign remittance inflows on poverty reduction in Botswana (Musakwa, and Odhiambo 2019), using a similar approach adopted by this study (the autoregressive distributed lag ARDL model) find that remittance inflows reduce poverty in Botswana on both short run and long run basis. This is in tandem with Azam et al (2016) who also finds that foreign remittance exerts positive impact on poverty reduction especially in uppermiddle-income countries. In the study Azum et al. (2016) remittance was found to be insignificant in high-income countries.

\section{Employment Status and Poverty}

Age dependency ratio of population as a proxy for unemployment, coded as lnagedprat

\subsection{Data analysis Technique}

Trend analysis was used in attaining objective (i). The second objective was attained using the bound co-integration testing approach proposed by Pesaran et al. (2001). The study conducted standard econometric diagnosis including Breusch-Godfrey serial correlation LM test, JacqueBera normality test, Breusch-Godfrey-Pagan test for heteroscedasticity, CUSUM test for stability 
and Ramsey RESET specification test were conducted following Studenmund (2001), Patterson (2000), Gujarati (2006) and Greene (2008).

The bounds test allows a mixture of $\mathrm{I}(1)$ and $\mathrm{I}(0)$ variables as regressors, therefore, the ARDL technique has the advantage of not requiring a specific identification of the order of the underlying data and it is quite suitable for small or finite sample size. In addition, the bound testing approach is applicable even when the explanatory variables are endogenous (Alam and Quazi 2003). The ARDL cointegration test, assumed that only one long run relationship exists between the dependent variable and the exogenous variables (Pesaran, et al, 2001, assumption 3). According to Pesaran et al (2001), the bound test is basically computed based on an estimated unrestricted errorcorrection models (UECM) or error correction version of autoregressive distributed lag (ARDL) model, by Ordinary Least Square (OLS) estimator. In the ARDL model, we test the null hypothesis of non-cointegrating relation (Ho: $\delta_{1}=\delta_{2}=\delta_{3}=\ldots=\delta_{\mathrm{n}}=0$ ) against the alternative hypothesis $\left(\mathrm{H}_{\mathrm{A}}: \delta_{1} \neq \delta_{2} \neq \delta_{3} \neq \ldots \neq \delta_{\mathrm{n}} \neq 0\right)$ (a long-run relationship exists). The estimated $F$-statistic value will then be evaluated using the critical values tabulated in Table CI (iii) of Pesaran et al. (2001). Thus the lower bound critical values assumed that the explanatory variables $x_{t}$ are integrated of order zero, or $\mathrm{I}(0)$, while the upper bound critical values assumed that $x_{t}$ are integrated of order one, or I(1). Hence, if the computed $F$-statistic is lower than the lower bound value, the null hypothesis is accepted and we conclude that there is no long-run relationship between the dependent variable and its determinants. On the other hand, if the computed $F$ statistic falls above the upper bound value, then the dependent variable and its determinants share a long-run level relationship. Conversely, if the computed $F$-statistic lies between the lower and upper bound values, the results are considered inconclusive.

Following Pesaran et al. (2001) and Atif et al. (2010) the vector autoregression (VAR) of order $p$, denoted $\operatorname{VAR}(p)$, for the following function were aggregated: $Z_{t}=\mu+\sum_{i=1}^{p} \beta_{i} z_{t-i}+\varepsilon_{t}$ 
1 where $z^{t}$ is the vector of both $x^{t}$ and $y^{t}$, where $y^{t}$ is the dependent variable defined as

2 household consumption expenses (lnhshdc) in this present study, $\mathrm{x}_{\mathrm{t}}$ is the vector matrix

3 representing a set of explanatory variables i.e., GDP per capita current USD (lngdp), export trade

4 calculated as exports of goods and services as percentage of GDP (lnexptrgdp), official exchange

5 rate of Nigerian Naira (NGN) to US dollars (USD) (lnforex), remittances inflows in USD to

6 Nigeria (lnremts), inflation rate (lninf) and age dependency ratio of population (proxy for

7 aggregate level of unemployment) (lnagedprat) and $t$ is a time or trend variable. According to

8 Pesaran et al. (2001), $\mathrm{y}_{\mathrm{t}}$ must be $\mathrm{I}(1)$ variable, but the regressor $\mathrm{x}_{\mathrm{t}}$ can be either $\mathrm{I}(0)$ or $\mathrm{I}(1)$. Then a

9 vector error correction model (VECM) was further developed as follows:

$$
\Delta z_{t}=\mu+\alpha t+\lambda z_{t-1}+\sum_{i=1}^{p-i} \gamma_{t} \Delta y_{t-i}+\sum_{i=1}^{p-1} \gamma_{t} \Delta x_{t-i}+\varepsilon_{t}
$$

where $\Delta$ is the first-difference operator. The long-run multiplier matrix $\lambda$ as:

$$
\lambda=\left[\begin{array}{l}
\lambda_{Y Y} \lambda_{Y X} \\
\lambda_{X Y} \lambda_{X X}
\end{array}\right]
$$

The diagonal elements of the matrix are unrestricted, so the selected series can be either $\mathrm{I}(0)$ or

$14 \mathrm{I}(1)$. If $\lambda_{Y Y}=0$, then $Y$ is I (1). In contrast, if $\lambda_{Y Y}<0$, then $Y$ is I(0).

The vector error correction mechanism (VECM) approaches described above are imperative in the testing of at most one cointegrating vector between dependent variable ${ }^{y_{t}}$ and a set of regressors $x_{t}$. To derive the model, the postulations made by Pesaran et al. (2001) in Case III, that is, unrestricted intercepts and no trends was followed.

The general co-integration hypothesis function can, therefore, be stated as the following unrestricted error correction model (UECM): 


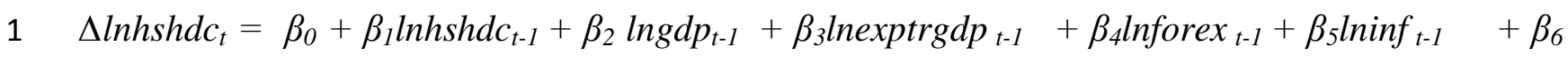

$\left.2\right|^{\text {Inagedprat }}{ }_{t-1}+\beta_{7}$ lnremts $_{t-1} \quad \beta_{8} \sum_{i=0}^{q} \Delta(\text { lnhshdc })_{t-1}+\beta_{9} \sum_{i=o}^{r} \Delta(\operatorname{lng} d p)_{t-1}+\beta_{10}$

3

4

5

6

$\sum_{i=0}^{s} \Delta(\operatorname{lnexptrgdp})_{t-1}+\beta_{11} \sum_{i=0}^{t} \Delta(\text { lnforex })_{t-1}+\beta_{12} \sum_{i=0}^{u} \Delta(\operatorname{lninf})_{t-1}+\beta_{13}$

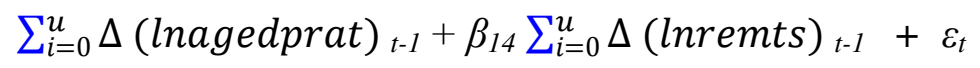

Where $\Delta$ is the first-difference operator and $\varepsilon$ is a white-noise disturbance term. All other variables are as earlier defined.

The Equation (2) can be estimated in two steps. In the first step, the null hypothesis of 'nonexistence of the long-run relationship' among the variables i.e. $\mathrm{H} 0$ : $\gamma \mathrm{k}=0$, is tested against the alternative of $\mathrm{H} 1$ : not all $\gamma \mathrm{k}$ are zero. where $\mathrm{k}=1,2, \ldots 7,19$. The relevant statistic in testing the null hypothesis is the usual F-statistic with new critical values tabulated by Pesaran, et al. (1996). Once the long run relationship i.e. the co-integration among the variables is confirmed, the following Error Correction Model (ECM) can be estimated at second step:

$\Delta \operatorname{lnhsdc}=\beta_{0}+\Sigma \beta_{\mathrm{i}} \Delta \operatorname{lnhsdc}-_{\mathrm{i}}+\delta \Sigma \Delta \mathrm{zt}-{ }_{\mathrm{j}}+\lambda \mathrm{ECt}-1+\mathrm{v}_{\mathrm{t}}$

Where, $\lambda$ indicates the speed of adjustment parameter and EC is residual obtained at the first step.

\section{Results and Discussion}

\subsection{Historical Trends in Migration Remittances outflows in Nigeria (1977 - 2010)}

Results of data analysis indicate that Nigeria recorded an increasing trend in international migration remittances outflows from 1977 to 1980. Shortly after this time, the trend started decreasing sharply. This could be as a result of a decrease in general standards of living which was associated the adoption of Structural Adjustment Programme (SAP) in mid-80s after Nigeria economy experienced a downturn exacerbated by international oil glut and poor governance. The situation ebbed in the early 2000s after the stabilization of the nation's democracy which encouraged inflows of Foreign Direct Investments (FDI) and we could see some moderate increase in the trend of international migrant remittances from 2001 upwards before decreasing at 

4 time.

about 2006 and stabilizing at 2009 -2014. Even though there have been a general upwards and downward swings in the outflow of international migration remittances in Nigeria, it could be summed up from the trend of the graph that the trend of this variable has been decreasing over

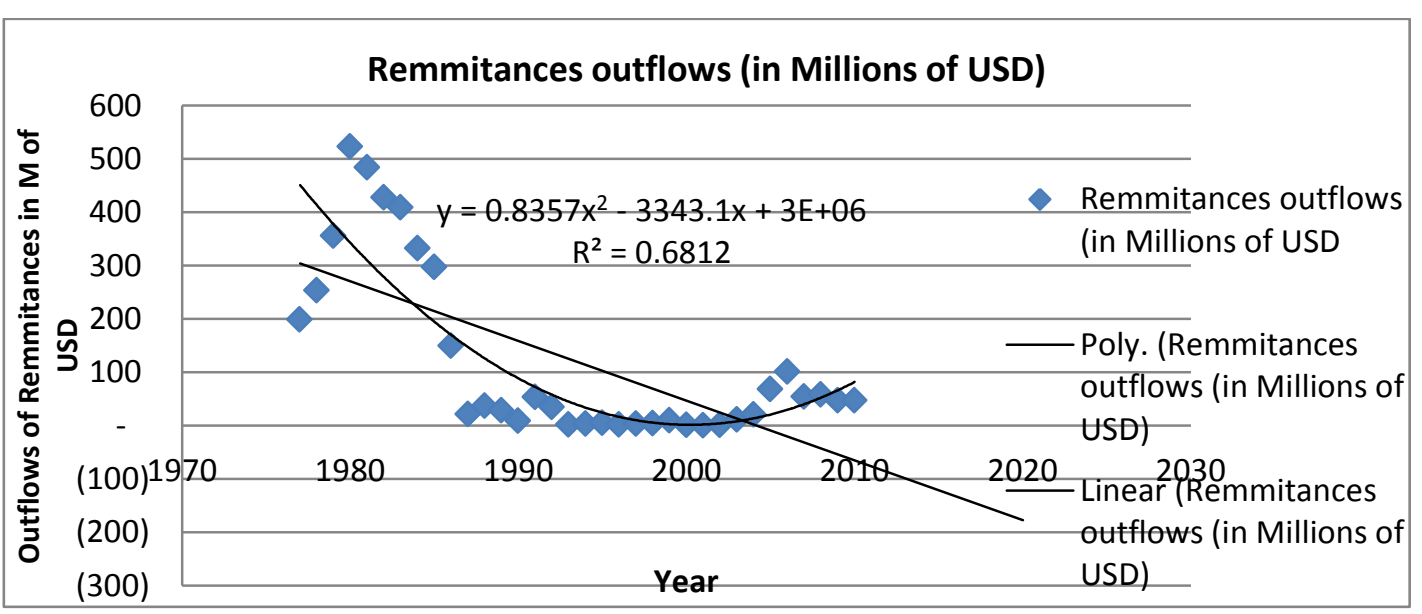

Figure 1: Graph illustrating the outflows of international migration remittances in Nigeria from 1977- 2014. Source:

Source: World Development Indicators (WDI) (World Bank, 2016)

Figure 2 shows trend in international migration remittances inflows to Nigeria over the period in review. The trend has been that of a relatively stable inflow of no foreign migration remittances into the country from 1977 till mid-2000s when the inflow drastically increased to about 180,000 (million USD). The figure then started a gentle increase from then henceforth.

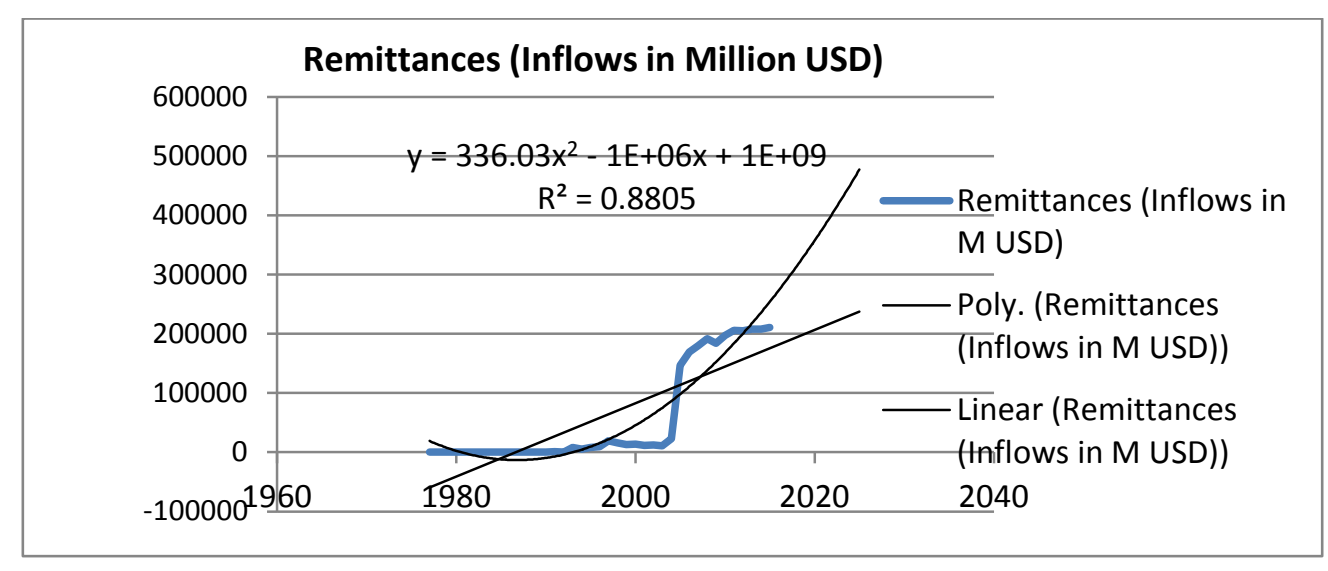


1 Figure 2: Graph illustrating the inflows of international migration remittances to Nigeria from 2 1977- 2014.

3 Source: World Development Indicators (WDI) (World Bank, 2016)

4

5 On the other hand, while net international migration was upwards before 1977 in Nigeria as indicated in Figure 3 the period between 1977 upwards in Nigeria had been consistently negative in terms of net migration. This implies that there had been more of emigration than immigration to Nigeria from 1977 to 2014.

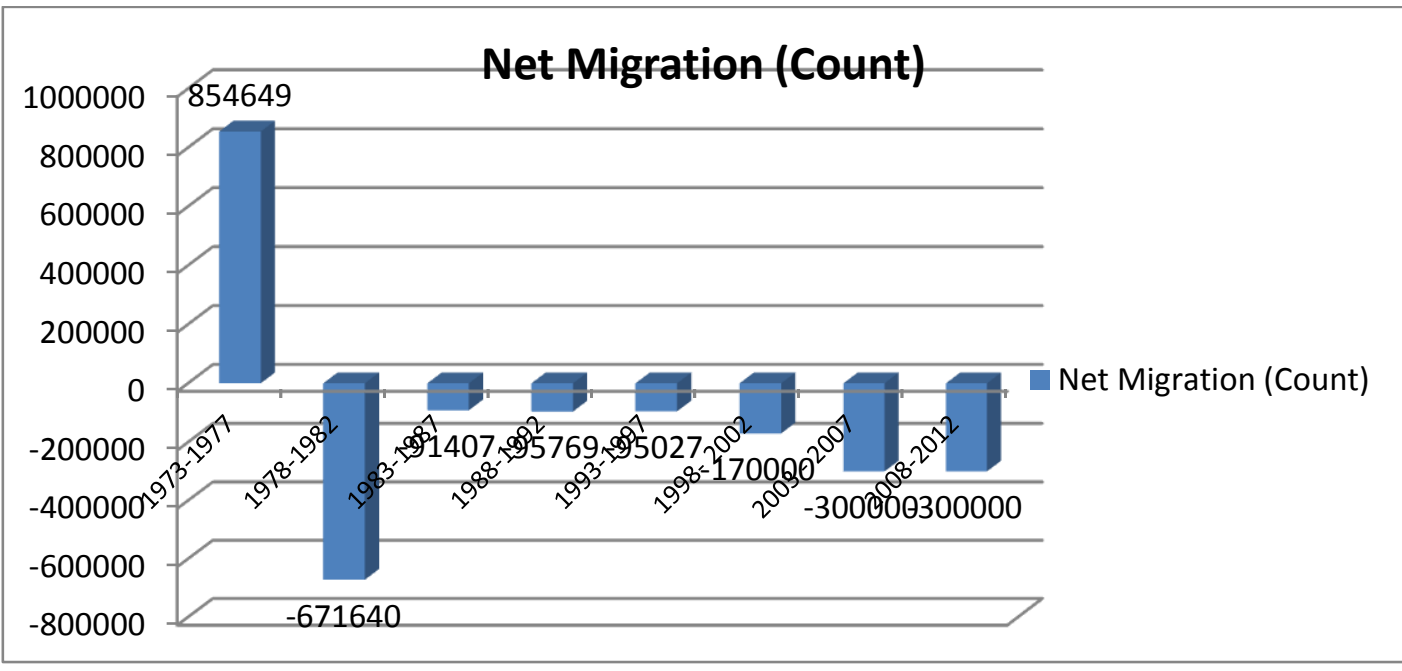

Figure 3: Bar Chart illustrating the net migration pattern recorded for Nigeria from 1977- 2014.

Source: World Development Indicators (WDI) (World Bank, 2016)

\subsection{Short- and Long-Run Effects of International Migration Remittances and}

\section{Macroeconomic Conditions on Aggregate Household Consumption in Nigeria}

The estimates of Equation (4) using the ARDL model is reported in Table 1. Using Hendry's general-to-specific method, the goodness of fit of the specification, that is, R-squared and adjusted R-squared, is 0.99 and 0.998 respectively. The implication of these is that the 99 percent variation in food production index was explained by the independent variables in the model. In the first step we first step, we estimated the various specifications of the Equation (4) and the most parsimonious estimation results are reported in Table 3. 
Table 1. Estimated Model Based on Equation 4

2 Dependent Variable : $\operatorname{lnHSHDC}$

\begin{tabular}{|c|c|c|c|c|}
\hline Variable & Coefficient & $\begin{array}{r}\text { Std. } \\
\text { Error }\end{array}$ & t-Statistic & Prob.* \\
\hline $\operatorname{lnhshdc}(-1)$ & -0.071 & 0.123 & -0.577 & 0.572 \\
\hline $\operatorname{lnhshdc}(-2)$ & 0.182 & 0.111 & 1.639 & 0.121 \\
\hline lnagedprat & -7.845 & 4.355 & $-1.801 *$ & 0.091 \\
\hline lnagedprat(-1) & 20.466 & 7.232 & $2.830 * *$ & 0.012 \\
\hline lnagedprat(-2) & -9.114 & 4.137 & $-2.203 * *$ & 0.043 \\
\hline lnexptrgdp & -0.295 & 0.055 & $-5.328 * * *$ & 0.000 \\
\hline $\operatorname{lnforex}$ & -0.087 & 0.053 & -1.645 & 0.120 \\
\hline $\operatorname{lnforex}(-1)$ & -0.061 & 0.052 & -1.176 & 0.257 \\
\hline $\operatorname{lnforex}(-2)$ & 0.257 & 0.046 & $5.625 * * *$ & 0.000 \\
\hline $\operatorname{lngdp}$ & 0.949 & 0.057 & $16.546 * * *$ & 0.000 \\
\hline $\operatorname{lngdp}(-1)$ & 0.142 & 0.118 & 1.205 & 0.246 \\
\hline $\operatorname{lngdp}(-2)$ & -0.310 & 0.104 & $-2.976 * * *$ & 0.009 \\
\hline $\operatorname{lngdp}(-3)$ & -0.077 & 0.054 & -1.430 & 0.172 \\
\hline $\operatorname{lninf}$ & -0.033 & 0.021 & -1.618 & 0.125 \\
\hline $\operatorname{lninf}(-1)$ & -0.039 & 0.019 & $-2.058 * *$ & 0.055 \\
\hline $\operatorname{lninf}(-2)$ & -0.055 & 0.028 & $-2.009 *$ & 0.062 \\
\hline lnremts & -0.002 & 0.021 & -0.090 & 0.929 \\
\hline lnremts(-1) & 0.024 & 0.021 & 1.113 & 0.282 \\
\hline lnremts(-2) & 0.032 & 0.017 & $1.929 *$ & 0.072 \\
\hline Intercept & 1.698 & 5.429 & 0.313 & 0.759 \\
\hline R-squared & 0.999 & & & \\
\hline Adjusted R-squared & 0.998 & & & \\
\hline S.E. of regression & 0.052 & & & \\
\hline Sum squared resid & 0.044 & & & \\
\hline Log likelihood & 69.843 & & & \\
\hline Akaike info criterion & -2.769 & & & \\
\hline F-statistic & 815.727 & & & \\
\hline $\operatorname{Prob}($ F-statistic $)$ & 0.000 & & & \\
\hline
\end{tabular}

3 NB: ***,** and * indicate significance at $0.01,0.05$ and 0.10 level respectively. Probability

4 values are quoted in square brackets.

6 In Table 2 the results of the bounds co-integration test demonstrate that the null hypothesis of no

7 co-integration against its alternative had to be rejected at the $1 \%$ significance level as indicated by

8 its very high F-ratio ( $\mathrm{F}=\mathbf{5 . 8 9 0}$ See Table 2$)$ which is significant at $1 \%$ and above bounds critical

9 level.

Table 2: Bounds Test for Cointegration Analysis 
ARDL Bounds Test

Null Hypothesis: No long-run relationships exist

\begin{tabular}{lcc}
\hline \hline Test Statistic & Value & $\mathrm{k}$ \\
\hline \hline F-statistic & $\mathbf{5 . 8 9 0 2 8 6}$ & 6 \\
\hline \hline \multicolumn{2}{l}{ Critical Value Bounds } & \\
\hline \hline Significance & I0 Bound & I1 Bound \\
\hline \hline $10 \%$ & 1.99 & 2.94 \\
$5 \%$ & 2.27 & 3.28 \\
$2.5 \%$ & 2.55 & 3.61 \\
$1 \%$ & 2.88 & 3.99 \\
\hline \hline
\end{tabular}

Note: Computed F-statistic: 5.890286 (Significant at 0.01 marginal values) for the restricted.

3 Critical Values are generated from EViews 9 software and based on Pesaran et al. (2001), Table

$4 \quad C I$ (iii), restricted intercept and no trend.

The computed $F$-statistic of 5.8903 recorded in the restricted constant double log model, which is greater than the upper critical bound value of 3.99, confirmed the existence of a steady-state longrun relationship among the series used for the study. The robustness of the model has been confirmed by several diagnostic tests such as Breusch-Godfrey serial correlation LM test, Breusch-Pagan-Godfrey test for heteroscedasticity and model stability test using CUSUM test. The model estimated (Table 2) passed different diagnostic tests. The F-statistic for serial correlation is $1.848635>\mathrm{p} 0.1940$, which indicates the absence of serial correlation using the Breusch-Pagan test. Jarque-Bera test statistic is $0.778>$ p 0.677 which confirms the normality of the residuals' distribution (See Figure 3). The model specification test done using Ramsey RESET test gave F-statistic estimate of 0.170942 (at $1,15 \mathrm{df}$ ) > p 0.6851, implying that the model is well specified. The Heteroskedasticity test using Breusch-Pagan-Godfrey test (F-statistics is 0.897366 $17>\mathrm{p}$ 0.5935) indicated there was no threat of severe heteroscedasticity in the model. The CUSUM tests of stability also confirm that the estimated model is stable as shown in Figures 4. 


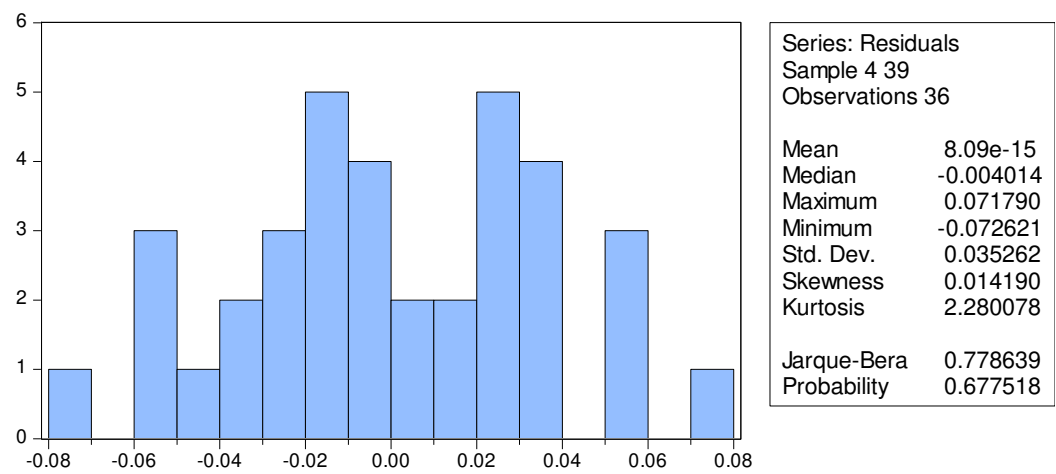

2 Figure 3: Results of Jarque-Bera test for normality of residuals estimated

3

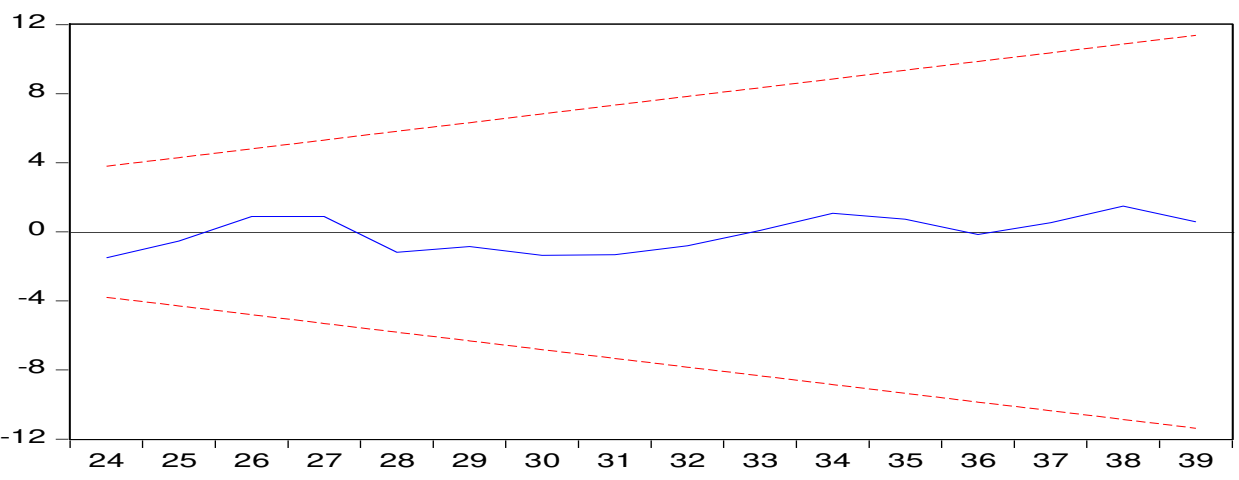

- CUSUM ---. 5\% Significance

$5 \quad$ Figure 4. Stability Test results with CUSUM Test at 5\% significance variables. The value of F-statistics, which is 5.890, already confirms the cointegration among the variables. Then we normalise the coefficients of lagged level variable by dividing on the coefficient of household consumption (lnhshdc) (assuming all the other coefficients are zero) and hence obtained the long run elasticities. The normalised equation is given in Table 3 . The results show that international migration remittances are positively related to aggregate household consumption and its impact is significant on the long run at a statistical significance level of $1 \%(\mathrm{t}$ ratio $=3.845)$. This outcome is not surprising. It is in tandem with Blench (2004) and specifically, Black et al (2004), who noted that "across West Africa, migration represents a significant livelihood strategy for poor people". It could be asserted therefore that this explains why this region, according to Black et al, had made some practical steps toward a more effective 
1

management of migration with the establishment of a regional consultative process. One of the outcomes of this process, which was initiated in 2000 by the IOM and the International Migration Policy Programme (IMP), they noted, is the Dakar Declaration signed by most West African countries and serving as a plan of action to promote the protection of migrants and to strengthen their role in development. The findings of this present study justify the thrust of the Dakar Declaration.

Table 3. Results of Long run coefficients of the effects of international remittances and macroeconomic factors on the level of aggregate household consumption in Nigeria

\begin{tabular}{lrrrr}
\hline \multicolumn{5}{c}{ Long Run Coefficients } \\
\multicolumn{1}{c}{ Variable } & Coefficient & \multicolumn{1}{c}{ Std. } & t-Statistic & Prob. \\
& \multicolumn{5}{c}{$\begin{array}{c}\text { Error } \\
\text { lnagedprat }\end{array}$} & 3.944 & 1.376 & $2.867 * * *$ & 0.011 \\
lnexptrgdp & -0.331 & 0.067 & $-4.970^{* * *}$ & 0.000 \\
lnforex & 0.123 & 0.022 & $5.555^{* * *}$ & 0.000 \\
lngdp & 0.793 & 0.055 & $14.486^{* * *}$ & 0.000 \\
lninf & -0.143 & 0.051 & $-2.829 * *$ & 0.012 \\
lnremts & 0.061 & 0.016 & $3.845^{* * *}$ & 0.001 \\
c & 1.910 & 5.973 & 0.320 & 0.753 \\
\hline
\end{tabular}

NB: $* * *, * *$ and $*$ indicate significance at $0.01,0.05$ and 0.10 level respectively. Probability values are quoted in square brackets.

$h s h d c=1.910+0.061 \operatorname{lnremts} * * *-0.143 \operatorname{lninf} * * *+0.793 \operatorname{lngdp} * * *+0.123 \operatorname{lnforex} * * *-0.331$

$\ln \exp \operatorname{trg} d p^{* * *}+3.944$ lnagedprat $* * *$

Results in Table 3 also indicated that household consumption at the aggregate level in Nigerian economy was determined on the long run by level of inflation, national income or GDP, foreign exchange rate, exports as a ratio of GDP and the proportion of aged in the total population of the economy (dependency ratio which also represents unemployment situation). These factors were all statistically significant at 1 percent level. These are in line with the findings of IMF (2001), 
1 Bonsu \& Muzindutsi (2017) and Mukherjee and Benson (2003) who observed that macroeconomic conditions influenced aggregate consumption significantly.

Now we estimate the error correction model as given in Equation (5). The results are presented in Table 4. Table 4 shows that error correction term has negative sign (coeff. $=-0.871, \mathrm{p}<0.01$ ) and significant at 1 percent level which confirms the existence of long run relationship at first step. The speed of adjustment coefficient, -0.871 is considerably low indicating a slow convergence to equilibrium in the case of a shock to the cointegrating relationship. From the result in the estimated cointegration equation, it is indicated that foreign migration remittances (lnremts) whose coefficients was 0.0608 in its natural $\log$ form, on the short-run, positively impacts on household consumption level in Nigeria. This means that a percentage increase in the international migration remittances is associated by an increase in aggregate household consumption in the country (Nigeria) by 6 percent. This affirms the relevance of migration to poverty alleviation in countries of migration origin as exemplified by Nigerian case here. However, this does not happen in isolation. Macroeconomic variables also combine to exert the observed effects of international migration on poverty reduction in the country. Other short run determinants of aggregate household consumption in the study as could be deduced from the cointegration equation are proportion of the aged in the country's population (lnagedprat), aggregate incomes that result from export trade of the country (lnexptrgdp) as well as the level of the economy's GDP (lngdp); foreign exchange rate (lnforex) and inflation rate in the economy.

Table 4: Short Run Dynamics (ECM) of Household Consumption

\begin{tabular}{|c|c|c|c|c|}
\hline \multicolumn{5}{|c|}{ Dependent Variable: Inhshdc } \\
\hline \multicolumn{5}{|c|}{ Selected Model: ARDL $(2,2,0,2,3,2,2)$} \\
\hline & Cointe & ating Form & & \\
\hline Variable & Coefficient & Std. Error & t-Statistic & Prob. \\
\hline $\mathrm{d}(\operatorname{lnhshdc}(-1))$ & -0.179 & 0.068 & $-2.619 * *$ & 0.019 \\
\hline
\end{tabular}




\begin{tabular}{|c|c|c|c|c|}
\hline $\mathrm{d}$ (lnagedprat) & -7.617 & 2.814 & $-2.707 * *$ & 0.016 \\
\hline $\mathrm{d}($ lnagedprat $(-1))$ & 8.853 & 2.795 & $3.167 * * *$ & 0.006 \\
\hline $\mathrm{d}(\operatorname{lnexptrgdp)}$ & -0.305 & 0.030 & $-10.028 * * *$ & 0.000 \\
\hline $\mathrm{d}(\operatorname{lnf}$ forex $)$ & -0.084 & 0.026 & $-3.217 * * *$ & 0.005 \\
\hline$d(\operatorname{lnforex}(-1))$ & -0.252 & 0.033 & $-7.546 * * *$ & 0.000 \\
\hline $\mathrm{d}(\operatorname{lngdp})$ & 0.952 & 0.036 & $26.348 * * *$ & 0.000 \\
\hline $\mathrm{d}(\operatorname{lngdp}(-1))$ & 0.381 & 0.068 & $5.569 * * *$ & 0.000 \\
\hline $\mathrm{d}(\operatorname{lngdp}(-2))$ & 0.072 & 0.036 & $2.016^{*}$ & 0.061 \\
\hline $\mathrm{d}(\operatorname{lninf})$ & -0.033 & 0.012 & $-2.821 * *$ & 0.012 \\
\hline $\mathrm{d}(\operatorname{lninf}(-1))$ & 0.054 & 0.012 & $4.603 * * *$ & 0.000 \\
\hline $\mathrm{d}($ lnremts) & -0.001 & 0.012 & -0.072 & 0.943 \\
\hline $\mathrm{d}(\ln r e m t s(-1))$ & -0.033 & 0.012 & $-2.638 * *$ & 0.018 \\
\hline ECM & -0.871 & 0.073 & $-11.993 * * *$ & 0.000 \\
\hline
\end{tabular}

$1 \quad$ Note: $\quad$ Cointeq $=$ lnhshdc $-(3.9439 * \ln a g e d p r a t-0.3313 * \ln$ exptrgdp $+0.1227 * \ln$ forex + $2 \quad 0.7926 * \ln g d p-0.1434 * \operatorname{lninf}+0.0608 *$ Inremts +1.9100$)$. $* * * * *$ and $*$ indicate significance at $3 \quad 0.01,0.05$ and 0.10 level respectively. Probability values are quoted in square brackets.

5 The effects of the export trade (which showed positive sign) on poverty (proxied by household 6 consumption level) was explained by Grounder (2012) and UNCTAD (2013) earlier. Meanwhile 7 the Error Correction factor (ECM), estimated was -0.871 , i.e. negatively signed in line with

8 theoretical expectation and significant at 1\% statistical level. This implies that there is a long-run causality between the determinants of consumption (including remittances) (with t-ratio of 11.993).

\section{Conclusion}

Against the backdrop of increasing international migration recently, with its mixed results of risks to human lives (both migrants and host citizens) and potential impacts on poverty alleviation on countries of origin, there was a need to properly contextualize migration in sustainable development goals (SDG) with empirical evidence on how foreign remittances impact on poverty

17 in Nigeria. There has been complains about the negative effects of migration on host countries.

With scanty empirical data available for migration management policies in different regions of the 
world, there was a need to assess how one of the major economies of Sub-Saharan Africa, Nigeria, where huge number of international migrants originate from, receive her effects of international migration with respect to her economic development (especially poverty reduction). Hence this study made attempts to chart the trend of migration remittances and net migration into and from Nigeria from 1977 to 2014 before assessing, rigorously, the impact of international migration on household consumption. It applied econometric modelling approach (using ARDL cointegration analysis) to determine the role of international migration remittances and other macroeconomic factors on the households' poverty level (proxied by aggregate household consumption). It was found that, while international migration remittances from Nigeria were reducing in a polynomial pattern, there was a sustained increase in the volume of international migration remittances to Nigeria from 70s to 2014 in a polynomial pattern. Meanwhile net migration pattern recorded for Nigeria from 1977-2014 was on the negative side, implying that there was more of emigration than immigration to Nigeria since 1977 . This situation can be associated with the growing poverty in the country as a result of poor economy and bad governance. Thus, immigration remittances from citizens of Nigeria became a very significant source of economic development input as it was observed from the study that the remittances exerted significant influence on the level of aggregate household consumption in the economy. Thus It was found that on the long run, when gleaned from the perspective of aggregate household consumption, level of poverty in the country could be explained by economic growth (GDP per capita current USD, lngdp), volume of export trade as percentage of GDP (lnexptrgdp), official exchange rate of Nigerian Naira to USD (lnforex), inflation rate (lninf) and age dependency ratio of population (proxy for aggregate level of unemployment) (lnagedprat). Based on the findings of the study, it was recommended that Nigerian government and other stakeholders in international development must make efforts to promote youth employment opportunities, enhance export market access to Small and medium scale enterprises, attain proper management of foreign exchange regimes and inflation to stabilize the economy to usher in prosperity. Since migration is not a sustainable source of income for the 
country, Nigerian authorities must provide education and skills acquisition opportunities too and enhanced working conditions to reduce dependency on immigration as a source of poverty reduction in households.

\section{Abbreviations}

SDGs: Sustainable Development Goals; GMDAC: Global Migration Data Analysis Centre; EU: European Union; IOM: International Organization for Migration; FAO: Food and Agricultural Organization; UN: United Nations; WDI: World Bank Development Indicators; CBN: Central Bank of Nigeria; NPISHs: Non-Profit Institutions Serving Households; IMF: International Monetary Fund; DFID: Department for International Development; UNCTAD: United Nations Conference on Trade and Development; GVC: Global Value Chains; ARDL: Autoregressive distributed lag model; UECM: unrestricted error-correction models; VECM: vector error correction model; SAP: Structural Adjustment Programme; FDI: Foreign Direct Investments.

(4)

\section{Acknowledgements}

Not applicable.

\section{Author contribution}

AOO is the main author and he conceptualized the main focus of the study and analyzed the data.

CC contributed to the literature review and proof-read the manuscript. Both authors read and approved the final manuscript.

\section{Funding}

University of South Africa (UNISA). 
1 Dataset analyzed in this study is available from the corresponding author upon reasonable request.

2

\section{Competing interests}

$4 \quad$ The authors of this work declare that they have no competing interests.

5

6 
APPENDIX 1. Results of Unit Root Tests using Augmented Dickey Fuller Test

\begin{tabular}{llll}
\hline VARIABLE OR & ADF & ADF 1 & REMARK \\
SERIES & STATISTICS AT & DIFFERENCE & \\
& LEVELS & STATISTICS &
\end{tabular}

\begin{tabular}{llll}
\hline lnagedprat & $-1.0694(\mathrm{NS})$ & $-6.0978 * * *$ & $\mathrm{I}(1)$ \\
lnexptrgdp & $-1.8901(\mathrm{NS})$ & $-8.3789 * * *$ & $\mathrm{I}(1)$ \\
& & & \\
lnforex & $-1.0726(\mathrm{NS})$ & $-5.1404 * * *$ & $\mathrm{I}(1)$ \\
lnhshdc & $0.9121(\mathrm{NS})$ & $-5.5250 * * *$ & $\mathrm{I}(1)$ \\
lngdp & $0.0634(\mathrm{NS})$ & $-5.5260 * * *$ & $\mathrm{I}(1)$ \\
lninf & $-3.747882(\mathrm{NS})$ & $-6.4636 * * *$ & $\mathrm{I}(1)$ \\
lnremts & $-1.0098(\mathrm{NS})$ & $-3.33933 * * *$ & $\mathrm{I}(1)$ \\
\hline
\end{tabular}

2 Note: The null hypothesis is that the series is non-stationary, or contains a unit root. The 3 rejection of the null hypothesis is based on MacKinnon (1996) critical values. The lag length are 4 selected based on AIC criteria, this ranges from lag zero to lag two. *, ** and *** indicate the 5 rejection of the null hypothesis of non-stationary at 1\%, $(t$ critical $=-3.605593)$, 5\% ( $t$ critical $-=$ 6 -2.9369) and 10\% (-2.607) significant level, respectively. This table was not explained in the 7 study because Pesaran (2001) noted that the order of integration must not be known ahead before 8 using the ARDL model; however we still conducted the test to provide further information on the 9 levels of cointegration of the series to more inquisitive minds. 


\section{References}

Abdih Y, Chami R, Dagher J, Montiel P (2011) Remittance and institutions: Are remittances a curse. World Devt, 40(4), 657-666. DOI:10.1016/j.worlddev.2011.09.014

Aggarwal R, Demirgüç-Kunt A, MartínezPería MS (2011) Do remittances promote financial development? Jnl of Devt Econs, 96, 255-264.

Atif RM, Jadoon A, Zaman K, Ismail A, Semab R (2010) Trade liberalisation, financial development and economic growth: evidence from Pakistan (1980-2009). Jnl of Int. Acad. Res. 10: 2.

Azam M, Haseeb M, Samsudin S (2016) The impact of foreign remittances on poverty alleviation: global evidence. Interdisc Approach Econ Sociol 9(1):264-281

Black R, Ammassari S, Mouillesseaux S, Rajkotia R (2004) Migration and Pro-Poor Policy in West Africa. Working Paper C8. Sussex Centre for Migration Research November 2004. Available at http://www.migrationdrc.org/publications/working_papers/WP-C8.pdf

Blench R (2004) Position paper: migration. London: DFID.

Bauer T, Zimmermann K (1995). Modelling international migration: economic and econometric issues. In Van der Erf, R. \& Heering, L. (eds), Causes of international migration. Proc. of a workshop, Luxembourg, 14-16 December 1994. Brussels: Eurostat.

Bonsu CO, Muzindutsi P (2017) Macroeconomic determinants of household consumption expenditure in Ghana: a multivariate cointegration approach. Intl. Jnl of Econs \& Fin. Iss, 2017, 7(4), 737-745

Central Bank of Nigeria, CBN (2015) Statistical Bulletin 26: Available at http://www.cbn.gov.ng/Out/2016/SD/2015\%20Statistical\%20Bulletin\%20Contents\%20an d\%20Narratives.pdf

Chiswick B (2000) Are immigrants favourably self-selected? An economic analysis. In: Brettel, C. and Hollifield, J. (eds), Migration theory. Talking across disciplines. New York: Routledge.

Chowdhury MB (2011) Remittances flow and financial development in Bangladesh. Economic Modelling, 28, 2600-2608. doi:10.1016/j.econmod.2011.07.013 
1 Gelderblom D (2006) A synthetic model of migration. In: P. Kok, D. Gelderblom, J. Oucho \& J. van Zyl (eds) Migration in South and Southern Africa. Dynamics and determinants. Cape Town: HSRC Press.

Glytos NP (1993) Measuring the income effects of migrant remittances: a methodological approach applied to Greece. The Univ. of Chicg: Retrieved on 10/06/2018 from http://www.journals.uchicago.edu/t-and-c)

Greene WH (2008) Econometric analysis, $5^{\text {th }}$ edition. New Delhi: McGraw Hill.

Grounder N (2012) The Determinants of Household Consumption and Poverty in Fiji". Griffiths Business School: In Nguyen, T. (Ed.). Discs. Papr No. 2012-05.

Gujarati DN (2006) Essentials of econometrics. $3^{\text {rd }}$ Edition. New York: Mc-Graw Hill.

Guiliano P, Ruiz-Arranz M (2009) Remittances, financial development, and growth. Jnl of Devt Econs, 90, 144-152. doi:10.1016/j.jdeveco.2008.10.005

Hamburger W (1954) The determinants of aggregate consumption. The Rev. of Econ. Stud, 22(1), 23-34. Retrieved July 17, 2020, from www.jstor.org/stable/2296221

Imai KS, Gaiha R, Ali A, Kaicker N (2014) Remittances, growth and poverty: New evidence from Asian countries. Journal of Policy Modeling, 36 (2014) 524-538.

International Monetary Fund and the World Bank (2001) Macroeconomic policy and poverty reduction. The IMF's Poverty Reduction and Growth Facility: A Factsheet. IMF. New York. Available: https://www.imf.org/external/pubs/ft/exrp/macropol/eng/

International Organization for Migration, IOM (2016) 2030 Agenda for Sustainable Development. International Organization for Migration IOM Office to the United Nations. Retrieved on 31/12/2016 from http://unofficeny.iom.int/2030-agenda-sustainable-development.

Iyare C (2016: 17 Dec.) Running from hunger in Nigeria to poverty in Europe. The Nigerian $\begin{array}{lllll}\text { Observer. } & \text { Retrieved } & \text { on } & \text { from }\end{array}$ https://nigerianobservernews.com/2016/12/running-from-hunger-in-nigeria-to-poverty-ineurope/\#.WGeYe_nrfIU

Musakwa MT, Odhiambo NM (2019) The impact of remittance inflows on poverty in Botswana: an ARDL approach. Econ. Structs 8, 42 (2019). https://doi.org/10.1186/s40008-019-0175$\mathrm{X}$ 
Nyan CF, Ming LC, Fan TA, Tien WM, Binn YS (2013) Relationship between remittances and Dutch Disease in Philippines. A research project submitted in partial fulfilment of the requirement of the degree of Bachelor of Economics (Hons) Finl Econs, Universiti Tunku Abdul Rahman, August, 2013. Available at : http://eprints.utar.edu.my/1107/1/FE-20131100111.pdf

Osili UO (2001) Remittances from international migration: an empirical investigation using a matched sample. Dept of Econs, Purdue University at Indianapolis. Indianapolis.

Pesaran MH, Shin Y, Smith R (2001) Bounds testing approaches to the analysis of level relationships, Jnl. of App. Econs, 16, 289-326.

Prahdan M (2009) Welfare Analysis with a Proxy Consumption Measure: Evidence from a Repeated Experiment in Indonesia. Fiscl Studs, 30 (3/4):391-417 Institute for Fiscal Studies, Blackwell Publishing Ltd: Available at https://onlinelibrary.wiley.com/doi/pdf/10.1111/j.1475-5890.2009.00101.x

Simmons A (1986) Recent studies on place-utility and the intention to migrate: an international comparison. Popn \& Envir/, 8 (1\&2):120-140.

Studenmund AH (2001). Using econometrics - a practical guide, Addison-Wesley-Longman :19395.

Todaro M (1976) Internal migration in developing countries. A review of theory, evidence, methodology and research priorities. Geneva: International Labour Office.

United Nations (2016) 244 million international migrants living abroad worldwide, new UN statistics reveal. Retrieved on 30/12/2016 from http://www.un.org/sustainabledevelopment/blog/2016/01/244-million-internationalmigrants-living-abroad-worldwide-new-un-statistics-reveal/

United Nations Conference on Trade and Development, UNCTAD (2013) The impact of trade on employment and poverty reduction. Trade and Development Board Trade and Development Commission, Fifth session Geneva, 17-21 June 2013. TD/B/C.I/29. Item 4 of the provisional agenda (25pp). Available at https://unctad.org/meetings/en/SessionalDocuments/cid29_en.pdf 
1 World Bank (2003) Quantitative techniques for health equity analysis-Technical note \#4: Tech.guidelns. for the quantitv. analysis of health equity. (11 pp). Available at https://www.eldis.org/document/A12640

4 World Bank (2016) World Development Indicators. The World Bank Group. Available at 5 http://data.worldbank.org

6 
Figures

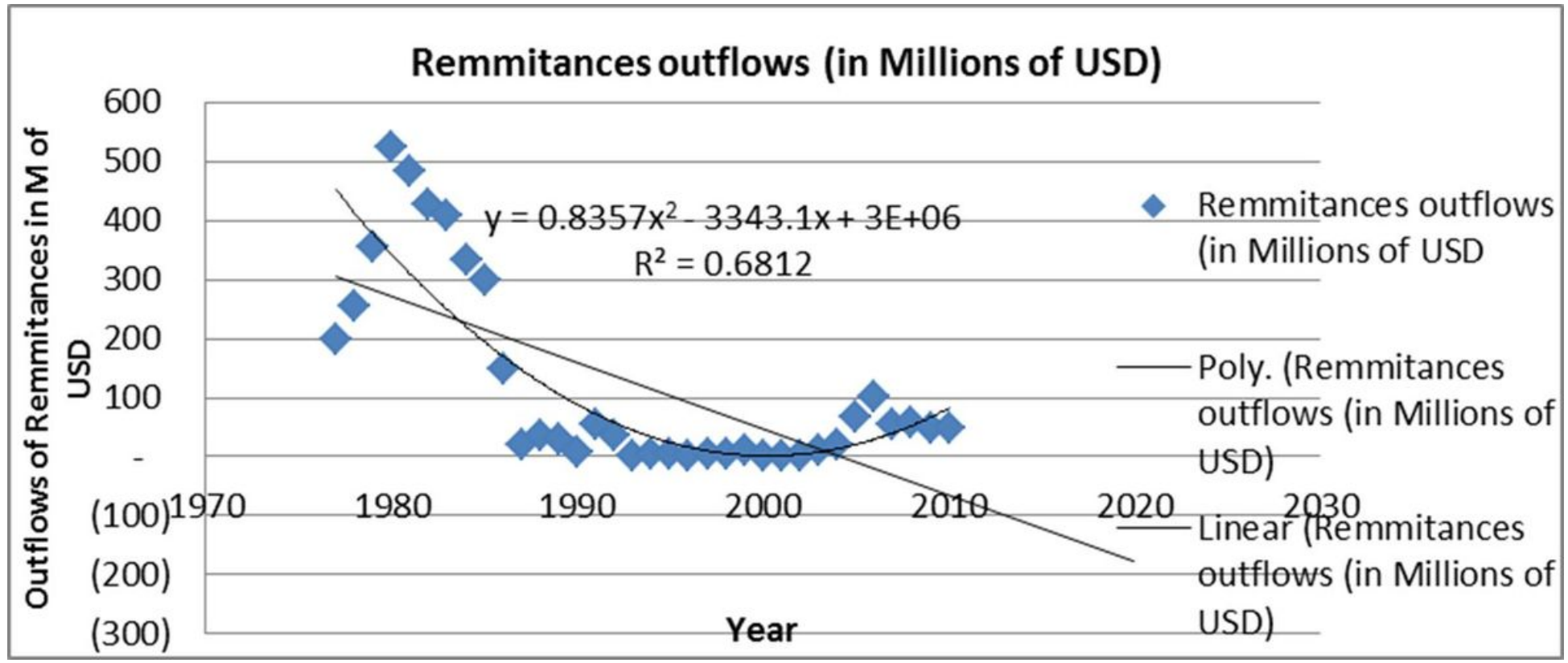

Figure 1

Graph illustrating the outflows of international migration remittances in Nigeria from 1977-2014. Source: Source: World Development Indicators (WDI) (World Bank, 2016)

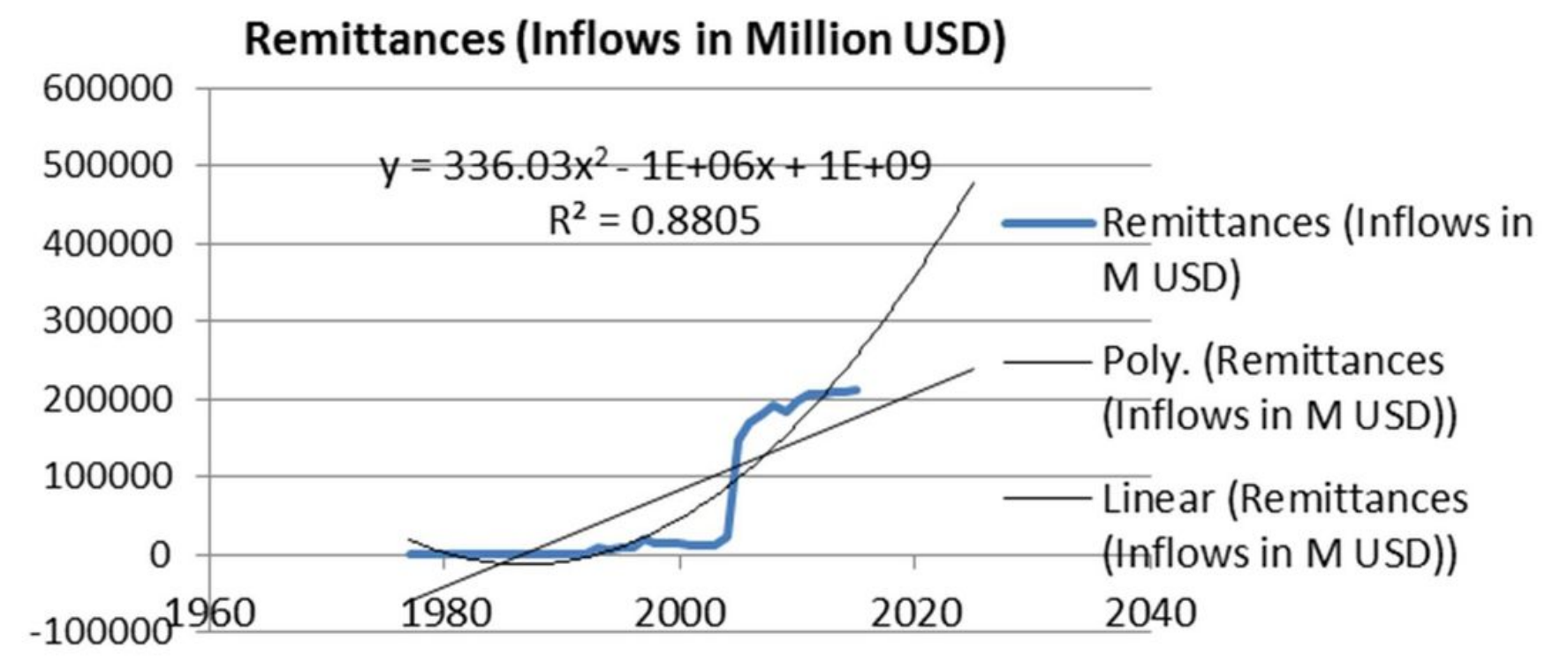

Figure 2

Graph illustrating the inflows of international migration remittances to Nigeria from 1977-2014. Source: World Development Indicators (WDI) (World Bank, 2016) 


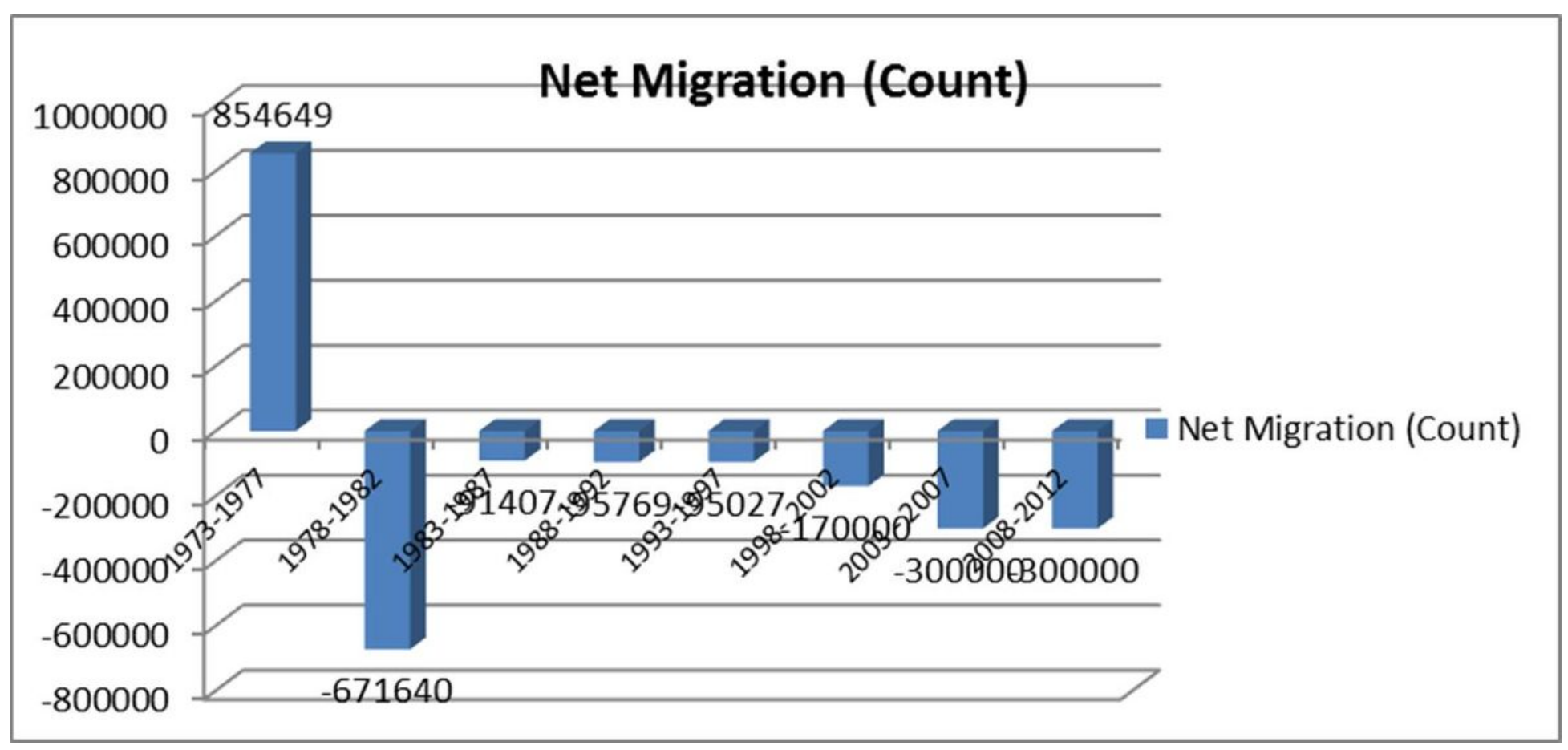

Figure 3

Bar Chart illustrating the net migration pattern recorded for Nigeria from 1977- 2014. Source: World Development Indicators (WDI) (World Bank, 2016)

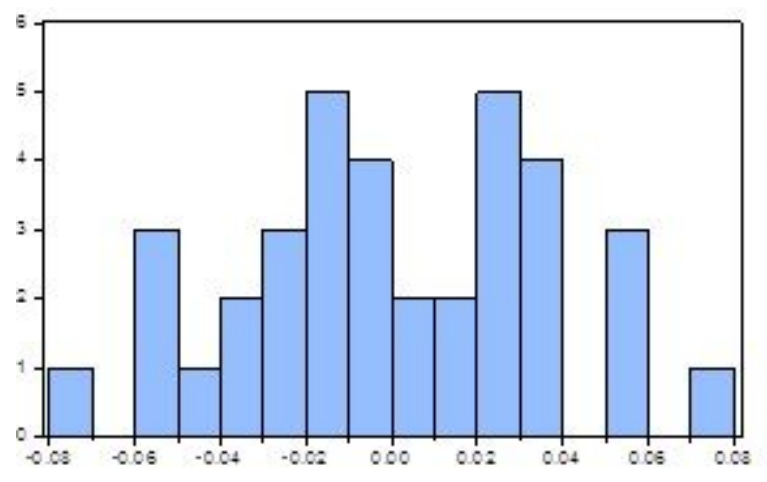

\begin{tabular}{|c|c|}
\hline \multicolumn{2}{|c|}{$\begin{array}{l}\text { Series: Residuals } \\
\text { Sample } 439 \\
\text { Observations } 36\end{array}$} \\
\hline $\begin{array}{l}\text { Mean } \\
\text { Median } \\
\text { Maximum } \\
\text { Minimum } \\
\text { Std. Dev. } \\
\text { Skewness } \\
\text { Kurtosis }\end{array}$ & $\begin{array}{r}8.09 \mathrm{e}-15 \\
-0.004014 \\
0.071790 \\
-0.072621 \\
0.035262 \\
0.014190 \\
2.280078\end{array}$ \\
\hline $\begin{array}{l}\text { brque-Bera } \\
\text { Probability }\end{array}$ & $\begin{array}{l}0.778639 \\
0.677518\end{array}$ \\
\hline
\end{tabular}

Figure 4

Results of Jarque-Bera test for normality of residuals estimated

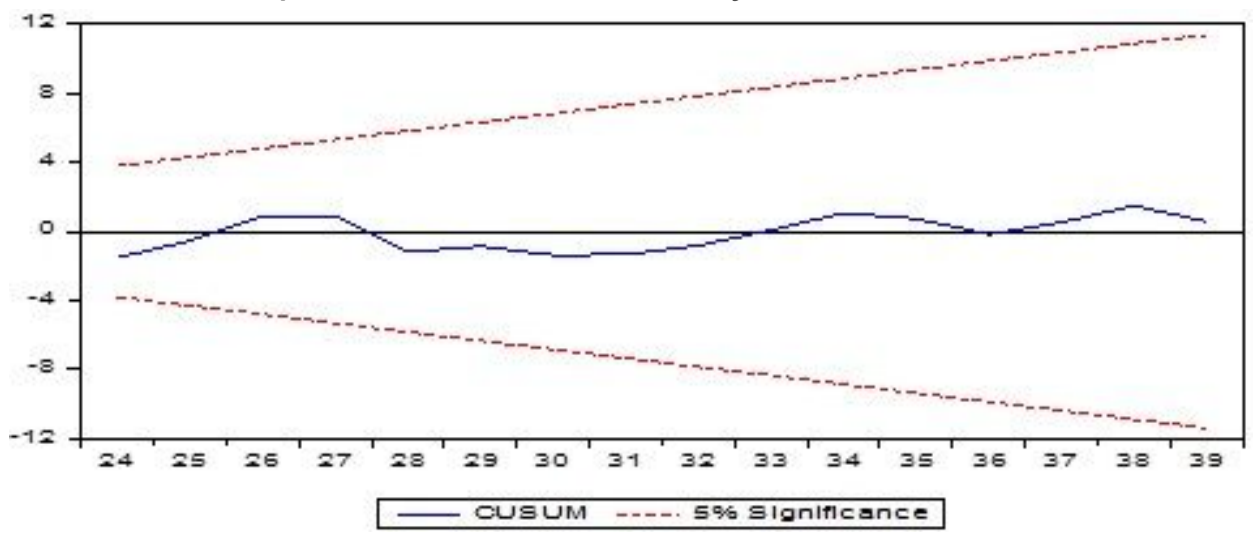


Figure 5

Stability Test results with CUSUM Test at $5 \%$ significance 